\title{
Subvolcanic contact metasomatism at El Laco Volcanic Complex, Central Andes
}

\author{
José A. Naranjo ${ }^{1}$, Fernando Henríquez ${ }^{2}$, Jan O. Nyström³ \\ 1 Servicio Nacional de Geología y Minería, Avda. Santa María 0104, Providencia, Santiago, Chile. \\ jnaranjo@sernageomin.cl \\ 2 Departamento de Ingeniería en Minas, Universidad de Santiago de Chile, Casilla 10233, Santiago, Chile. \\ fernando.henriquez@usach.cl \\ 3 Swedish Museum of Natural History, Box 50007, SE-104 05 Stockholm, Sweden. \\ jan.nystrom@nrm.se
}

\begin{abstract}
Studies of drill cores from the Pasos Blancos area at El Laco in the central Andes, northern Chile, give evidence of an intense and extensive subvolcanic contact-metasomatic process. This process resulted from shallow-level emplacement of very volatile-rich iron-oxide magma, with discharge of volatiles that resulted in extensive fracturing of overlying volcanic rocks. The brecciated rocks were altered (mainly extensive scapolitization and formation of pyroxene) by hot magmatic fluids emitted from the cooling intrusion, and accompanied by magnetite deposition. With time and decreasing temperature, the metasomatic fluids evolved to fluids of hydrothermal character, and a final recent geothermal event took place that deposited superficial gypsum over a large part of the El Laco Volcanic Complex.
\end{abstract}

Keywords: Contact metasomatism, Iron oxide magmas, El Laco, Northern Chile, Andes.

RESUMEN. Metasomatismo de contacto subvolcánico en el Complejo Volcánico El Laco, Andes centrales. Estudios realizados en testigos de sondajes en el área de Pasos Blancos en El Laco, en los Andes Centrales del norte de Chile, dan evidencias de un intenso y extenso proceso subvolcánico de metasomatismo de contacto. Este proceso es el resultado de un emplazamiento a poca profundidad de un magma de óxido de fierro muy rico en volátiles y cuya descarga de gases produjo un intenso fracturamiento de las rocas sobrepuestas. Las rocas brechizadas fueron alteradas (principalmente una extensa escapolitización y formación de piroxeno), junto con la depositación de magnetita, por los fluidos magmáticos calientes emitidos por la intrusión durante su enfriamiento. Los fluidos metasomáticos evolucionaron en el tiempo y con la disminución de temperatura, a fluidos de carácter hidrotermal y finalmente tuvo lugar un evento geotérmico reciente, el cual depositó yeso superficial en gran parte del Complejo Volcánico El Laco. 


\section{Introduction}

Since their discovery in the early 1960's (Park, 1961), the iron-oxide ore bodies at El Laco have been suggested to have formed from a volatile-rich, iron-rich magma which intruded a Plio-Pleistocene volcanic complex at shallow depth and at places erupted onto the surface (Naslund et al., 2002, and references therein; Henríquez et al., 2003, 2004; Naranjo et al., 2004; Nyström et al., 2008). However, a hydrothermal origin has also been proposed for the El Laco orebodies (Larson, 1994; Rhodes and Oreskes, 1994, 1995, 1999; Oreskes et al., 1994; Rhodes et al., 1999; Sillitoe and Burrows, 2002; Sillitoe, 2003).

The owner of the iron deposits, Compañía Minera del Pacífico (CMP), has carried out an extensive program of drilling at El Laco in recent years (2007-2008). This program has included $c a$. $3,310 \mathrm{~m}$ of drill core, with one drill hole attaining a maximum depth of approximately $500 \mathrm{~m}$ in the Pasos Blancos area where no iron ore crops out (Fig. 1). The purpose of this work is to document new geological features at depth within this area, which give new information about the evolution of this unique volcanic complex.

\section{El Laco volcanic geology}

The El Laco Volcanic Complex (ELVC) in the central Andes is a Plio-Pleistocene cluster of andesitic to dacitic volcanic structures comprising seven or more minor stratovolcanoes and domes at altitudes of 4,600-5,200 m a.s.l. Some of these volcanic sources, which are distributed within an area of $30 \mathrm{~km}^{2}$, have erupted iron oxide as lavas and pyroclasts (e.g., Henríquez et al., 2004). The iron-oxide volcanics are largely composed of magnetite except in surface outcrops of major deposits that resemble lava flows, where hematite formed by martitization of magnetite predominates. Other minerals present are fluorapatite and pyroxene, typically in minor-trace amounts.

These volcanic products most probably evolved independently from a common magmatic chamber, based on the magnetic modelling by Alva et al. (2003) that inferred the presence of a large magnetite body at depth in the Pasos Blancos area. Iron-oxide lava flows and pyroclastic density current deposits are found at many places in the ELVC. Lava flows, domes and pyroclastics of andesitic-dacitic composition were erupted from central craters of the stratocones.
Iron-oxide lavas and pyroclastics, on the other hand, appear to have been erupted from independent parasitic vents, mostly fissures. The iron-oxide bodies occur interfingered with the andesitic volcanic products. K-Ar dating carried out at the laboratories of the Servicio Nacional de Geología y Minería (Sernageomin) of nine samples of andesite lavas and sub-volcanic rocks from different structures in the ELVC have given ages of between 5.3 and 1.6 Ma (Table 1). Structures in silicate lavas interpreted as ice-contact features were attributed to Upper Pliocene glaciations (Naranjo et al., 2008). These ages are in agreement with fission-track dating of apatite from the iron-oxide ore (2.1 $\pm 0.1 \mathrm{Ma}$; Maksaev et al., 1988) and previous K-Ar dating of andesite lava (2.0 \pm 0.3 Ma; Gardeweg and Ramírez, 1985).

Extensive late Pleistocene moraine deposits crop out immediately to the west of El Laco. They were produced by glacier tongues that affected both the ELVC and the Pleistocene Puntas Negras volcano further west. Hammerschmidt et al. (1999) determined He and Ne cosmogenic ages in pyroxene crystals obtained from ice-polished lava surfaces at El Laco and reported values of 226 and $287 \mathrm{ka}$, respectively. Consequently, nonglacial erosional rates in the ELVC area are low.

\section{Contact metasomatism}

Drilling in the Pasos Blancos area in 2007 and 2008 yielded a total of 3,310 m of drill core. Ten holes with a maximum vertical depth of $444.35 \mathrm{~m}$ (one $500.5 \mathrm{~m}$ long core is from a $60^{\circ}$ oblique hole) were drilled in a one by one kilometer area (Fig. 1). Drill cores were logged, sampled and photographed. Representative samples were analyzed by XRD at Sernageomin and the Swedish Museum of Natural History, and polished thin sections were studied in order to determine the mineralogy and textures.

The rocks in all the drill cores are breccias with some well-preserved fragments of andesite and rare dacite protoliths, as well as fragments of magnetite. However, some, or most, of the original minerals of the rock fragments are commonly replaced by other phases. The breccia matrix consists of magnetite, scapolite and pyroxene (diopside) (Fig. 2a).

The intensity of the alteration increases with depth. At higher levels the rock fragments are angular, and have reaction rims composed of scapolite and less pyroxene (Figs. 2b and 2c). At depth the fragments are strongly replaced by scapolite and some pyroxene 


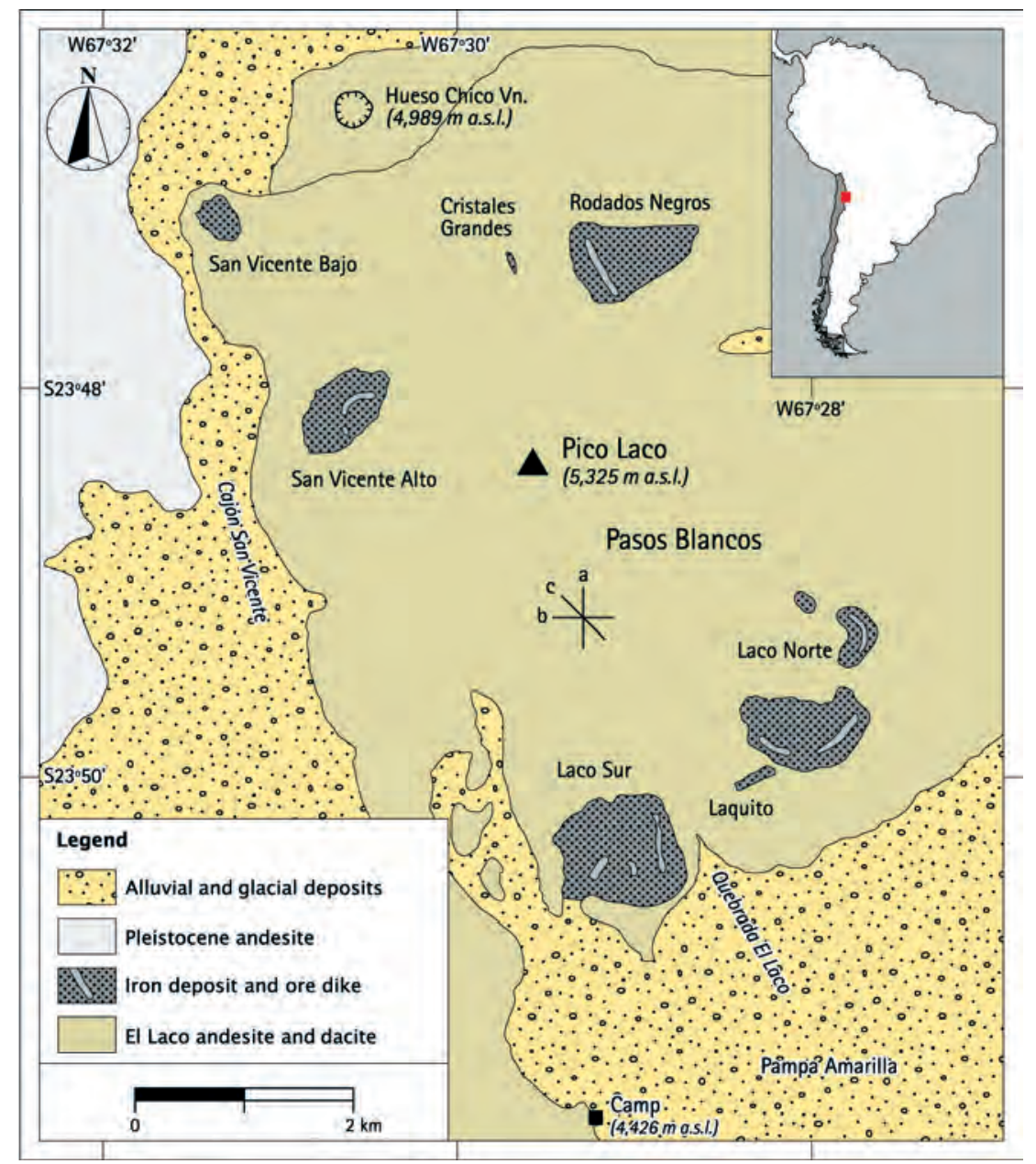

FIG. 1. Geological sketch map of the El Laco Volcanic Complex showing the Pasos Blancos area where the location of drill core profiles a, b and c are indicated.

(Fig. 2d). Fragments that are totally replaced tend to have rounded shapes due to metasomatic reactions. Magnetite is abundant at depth in most drill cores. Gypsum occurs in veins and open spaces and represents the last stage in the alteration process.

The following minerals have been observed in the drill cores and confirmed by XRD: magnetite, scapolite, pyroxene, titanite, natrolite (zeolite mineral), apatite, gypsum, bassanite $\left(\mathrm{CaSO}_{4} \cdot 1 /{ }_{2} \mathrm{H}_{2} \mathrm{O}\right)$, mica, alunite and tridymite. Additional minerals identified in polished thin sections are pyrite, garnet, mica and chalcopyrite. The main characteristics of the identified minerals are as follows:

Magnetite. Magnetite is abundant in the lower parts of most of the drill cores. It occurs as veins and veinlets in the breccias, as breccia fragments (Fig. 3a), and as disseminations in the matrix of breccias and rock fragments. Three generations of magnetite are recognized. The first is represented by brecciated massive magnetite fragments and veins. In almost unaltered andesite it also occurs as grains and inclusions in plagioclase phenocrysts, both with rims of tiny plagioclase crystals with the appearance of microlites. The second generation is represented by magnetite veins and veinlets that cut the breccias, and have a hematite oxidation halo associated with a rim of scapolite and pyroxene (Fig. 3b). The third generation corresponds to pyrite-bearing magnetite veinlets that cross-cut all previously formed phases. Scapolite. Two generations of scapolite are recognized. The first is represented by the partial to complete replacement of plagioclase phenocrysts 
TABLE 1. K-Ar DATING ANALYTICAL PARAMETERS AND RESULTS FOR SAMPLES OF ELVC.

\begin{tabular}{|c|c|c|c|c|c|c|c|}
\hline Sample No. & Latitude S & Longitude W & $\begin{array}{c}\text { Analized } \\
\text { material }\end{array}$ & $\% \mathrm{~K}$ & $\begin{array}{c}\text { Rad. Ar } \\
\text { nl/g }\end{array}$ & $\begin{array}{l}\% \text { Ar } \\
\text { Atm }\end{array}$ & 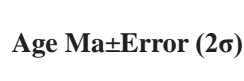 \\
\hline $260103-2(*)$ & $23^{\circ} 47.8^{\prime}$ & $67^{\circ} 29.8^{\prime}$ & Whole rock & 1.757 & 0.283 & 97 & $4.1 \pm 2.6$ \\
\hline $260103-2(*)$ & & & Whole rock & $”$ & 0.446 & 95 & $6.5 \pm 2.7$ \\
\hline \multicolumn{7}{|c|}{ (*) Weighted mean between these two results } & $5.3 \pm 1.9$ \\
\hline 260103-3 (*) & $23^{\circ} 48.2^{\prime}$ & $67^{\circ} 29.9^{\prime}$ & Whole rock & 0.894 & 0.085 & 95 & $2.4 \pm 1.4$ \\
\hline 260103-3 (*) & & & Whole rock & $”$ & 0.090 & 92 & $2.6 \pm 0.6$ \\
\hline \multicolumn{7}{|c|}{$(*)$ Weighted mean between these two results } & $2.6 \pm 0.6$ \\
\hline 260103-6 & $23^{\circ} 47.8^{\prime}$ & $67^{\circ} 31.3^{\prime}$ & Whole rock & 1.447 & 0.215 & 87 & $3.8 \pm 0.9$ \\
\hline $260103-7$ & $23^{\circ} 47.5^{\prime}$ & $67^{\circ} 30.8$ & Biotite & 7.184 & 0.583 & 89 & $2.1 \pm 0.4$ \\
\hline $250103-2$ & $23^{\circ} 50^{\prime}$ & $67^{\circ} 28.5^{\prime}$ & Whole rock & 1.42 & 0.204 & 91 & $3.7 \pm 0.9$ \\
\hline $250103-3$ & $23^{\circ} 49.4^{\prime}$ & $67^{\circ} 28.8^{\prime}$ & Whole rock & 1.315 & 0.101 & 73 & $2.0 \pm 0.3$ \\
\hline $250103-4$ & $23^{\circ} 49.3$ & $67^{\circ} 28.8^{\prime}$ & Whole rock & 1.307 & 0.101 & 90 & $2.0 \pm 0.6$ \\
\hline 250103-6 (*) & $23^{\circ} 49.2^{\prime}$ & $67^{\circ} 29.7^{\prime}$ & Whole rock & 1.595 & 0.214 & 96 & $3.4 \pm 1.7$ \\
\hline 250103-6 (*) & & & Whole rock & $”$ & 0.293 & 96 & $4.7 \pm 2.2$ \\
\hline \multicolumn{7}{|c|}{$(*)$ Weighted mean between these two results } & $3.9 \pm 1.3$ \\
\hline 250103-8 & $23^{\circ} 50.7$ & $67^{\circ} 29.9^{\prime}$ & Whole rock & 1.792 & 0.110 & 94 & $1.6 \pm 0.5$ \\
\hline
\end{tabular}

Note: analyses carried out at the Geochronology Laboratory of Sernageomin, Chile.

and groundmass in rock fragments by scapolite (Fig. 3b). The mineral forms conspicuous reaction halos in partly altered breccias (Fig. 2c). Scapolite is also a major constituent of the breccia matrix (Figs. 2a and 3c). This scapolite occurs as up to millimeter-sized, prismatic, white-translucent crystals. It is marialite according to electron microprobe analyses of samples from an old drill core at Pasos Blancos. The second generation of scapolite is represented by aggregates of up to 3 cm long prismatic crystals in open spaces (Fig. 3d). Pyroxene. Well-formed, up to $1 \mathrm{~mm}$ green crystals of pyroxene typically showing mosaic texture. The mineral occurs in the matrix of the breccias and rock fragments, and as reaction halos around fragments. Pyroxene is also found as rims of magnetite veins that cut breccia fragments and matrix (Figs. 2d and 4a).

Titanite. Some titanite is present as euhedral crystals associated with scapolite in open spaces (Fig. 4b). The mineral also occurs in the breccia matrix (Fig. 3a). Natrolite. Natrolite occurs as pink needle-shaped (up to $5 \mathrm{~mm}$ ) and microgranular crystals in open spaces. Garnet. Up to $2 \mathrm{~mm}$-size crystals of garnet are disseminated in the breccia matrix. In an old drill core from Pasos Blancos, the garnet has been determined to be Ti-bearing andradite-grossularite (microprobe analysis).

Apatite. Submillimeter-sized crystals of apatite can be observed in andesite fragments. Apatite occurs less commonly as up to $1-2 \mathrm{~cm}$ long, euhedral crystals of pale yellow-green color in open spaces (Fig. 4c). Chemically and supported by XRD, the mineral is fluorapatite.

Pyrite. Pyrite is associated with magnetite veinlets of the second generation, and occurs disseminated in the matrix of breccias as well as rock fragments. Microscopic veinlets of pyrite cut magnetite.

Chalcopyrite. Although very scarce, some grains of chalcopyrite are observed disseminated in the matrix of breccias.

Mica. A mica mineral with weak pleochroism in transmitted light, indicating a low iron content, is observed in thin sections. It is probably phlogopitic mica because such a phase has been observed in an old drill core from Pasos Blancos and elsewhere at El Laco (Rodados Negros). According to microprobe analyses this mica is very rich in fluorine (5-7 $\mathrm{wt} \% \mathrm{~F}$ ) and poor in chlorine. 

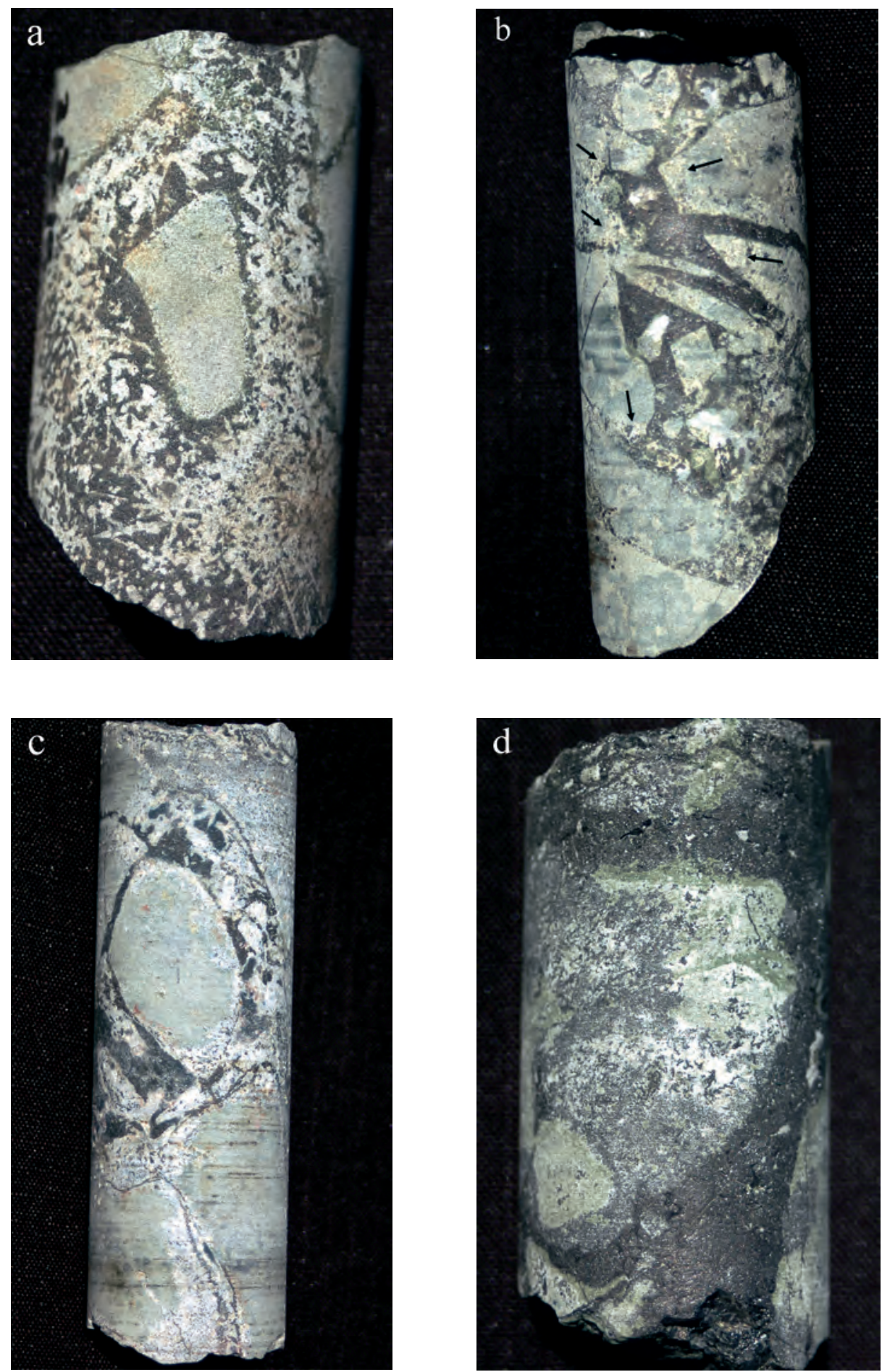

FIG. 2. a. Breccia with slightly rounded andesite fragments rimmed by scapolite-(pyroxene)-magnetite in a matrix of scapolite-magnetite-(pyroxene). Scapolite is white in color with mostly prismatic habit. The diameter of the drill core in this and all the following photos is $4.5 \mathrm{~cm}$ (DDH-0812; $317.15 \mathrm{~m}$ deep); b. Angular fragments of andesite with scapolite rims (arrows) in a magnetite-pyroxene matrix. (DDH-0807; $375.75 \mathrm{~m}$ deep); c. Brecciated andesite with scapolitization along fragment rims (small fragments are completely replaced). The matrix consists of magnetite and prismatic crystals of scapolite (white) (DDH-0807; 252.45 m deep); d. Different generations of magnetite in a breccia with slightly rounded andesite fragments totally replaced by pyroxene (green) and scapolite (white). The fragments are rich in disseminated magnetite. The matrix of the breccia consists of magnetite and minor scapolite (DDH-0812; $394.55 \mathrm{~m}$ deep). 

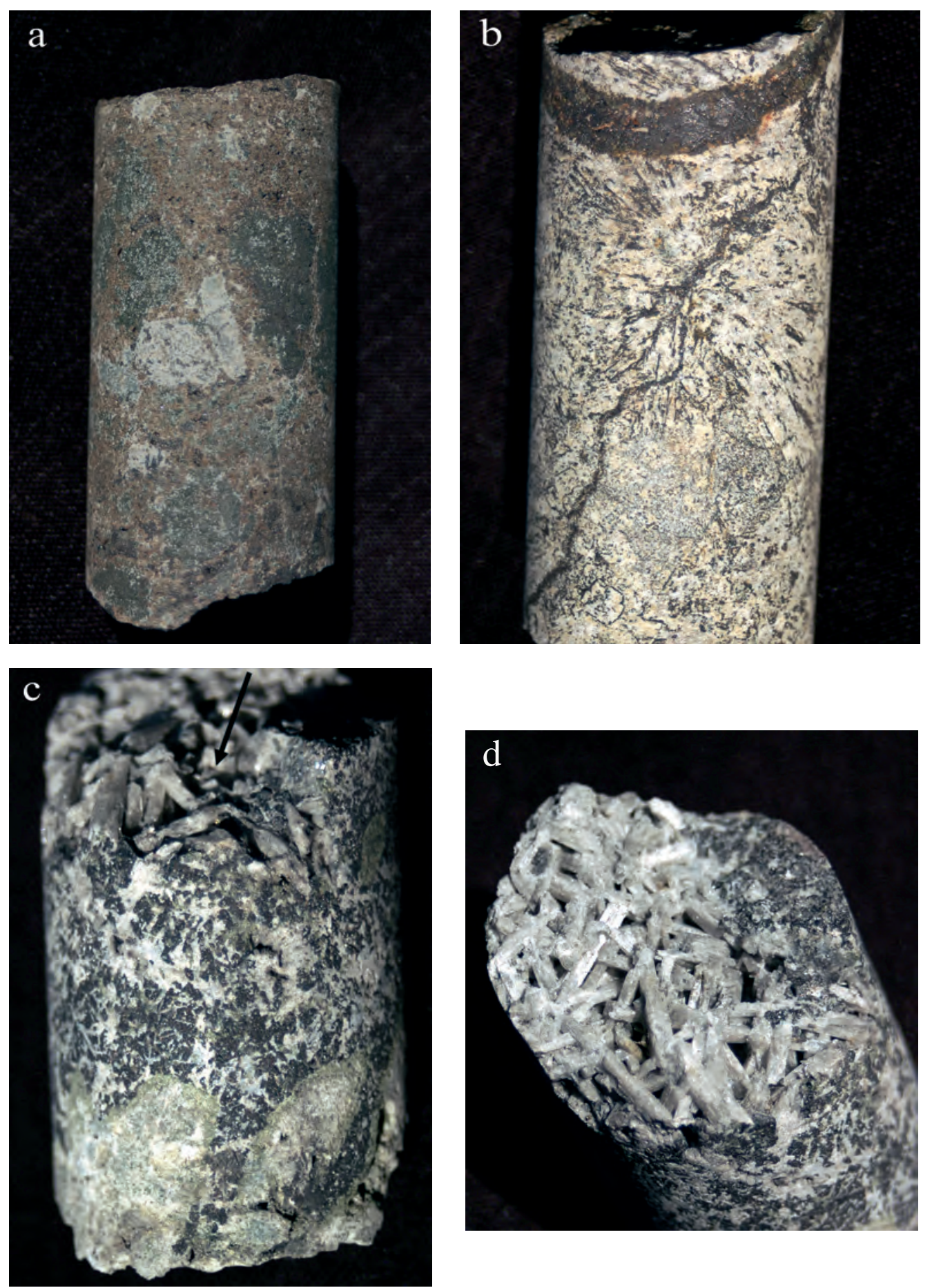

FIG. 3. a. Breccia with rounded fragments of altered andesite and magnetite in a titanite-dominated matrix (brownish). The diameter of the drill core in this and all the following photos is $4.5 \mathrm{~cm}$ (DDH-0807; $161.40 \mathrm{~m}$ deep); b. Rock fragments totally replaced by scapolite (white) and disseminated magnetite in a matrix of intergrown scapolite-magnetite. The breccia is cut by second-generation magnetite (see text) veinlets and a magnetite vein with pyroxene (green) which is slightly oxidised at the margins, on the upper part of the photograph (DDH-0807; $207.10 \mathrm{~m}$ deep); c. Breccia with totally scapolitized rock fragments rimmed by pyroxene in a magnetite-scapolite matrix. Large scapolite crystals (arrow) occur in a cavity. (DDH-0809; $274.6 \mathrm{~m}$ deep); d. Prismatic scapolite crystals of the second generation (see text) in a cavity (DDH-0809; 274.6 m deep, section view). 

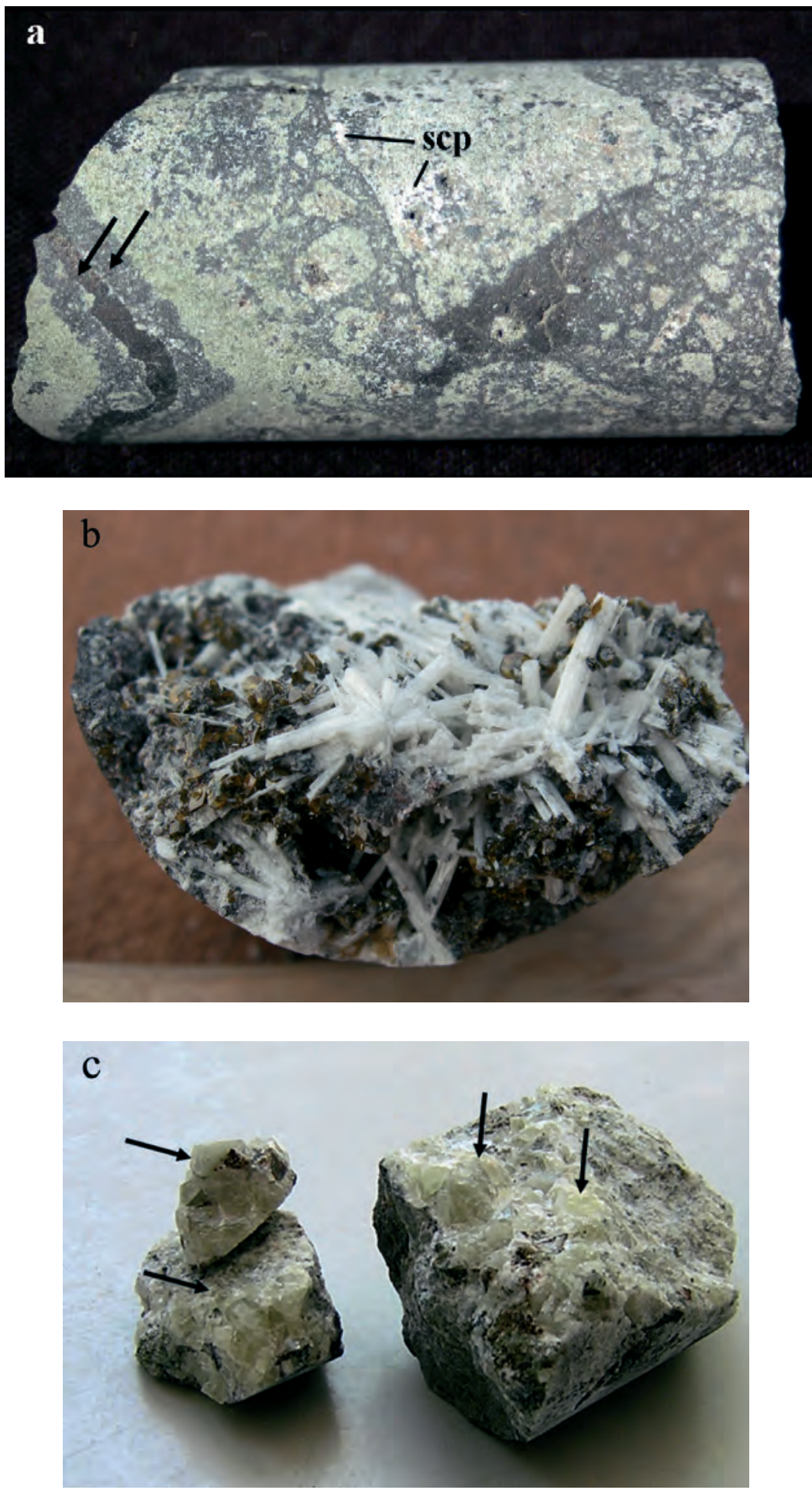

FIG. 4. a. Fragments of andesite protolith with scapolite (scp), pyroxene (green) and magnetite in a magnetite-dominated matrix. Some fragments are rounded due to alteration. A ‘two-step’ magnetite vein rimmed by scapolite and pyroxene occurs (arrows) (DDH-0810; $394.20 \mathrm{~m}$ deep); b. Euhedral crystals of titanite and scapolite in a cavity (DDH-0813; $284.7 \mathrm{~m}$ deep); c. Coarse apatite crystals in a cavity (arrows) (DDH-0811; 319.9 m deep). 
Based on the relative abundances of scapolite and pyroxene, the presence of totally replaced rounded fragments versus angular less altered fragments of andesite, and the presence or absence of reaction rims, the following units were defined during drill core logging: hydrothermal breccia; andesite with an imprint of low-intensity contact metasomatism, breccia with high-intensity contact metasomatism, and breccia with high-intensity contact metasomatism and iron-oxide mineralization. These units are shown in schematic drill core profiles in figure 5.

Study of the drill cores from Pasos Blancos allows the identification of four stages during the contact metasomatic-hydrothermal alteration process at $\mathrm{El}$ Laco. Their characteristic mineralogies are summarized in table 2.

The first stage is characterized by formation of breccias and dikes/veins of magnetite, with crystallization of magnetite in the matrix, and magnetite with microlitic plagioclase rims in andesite. Magnetite is ubiquitous in drill cores from all levels. The magmatic character of the magnetite of this stage is inferred from features similar to those found in magnetite dikes that crop out at Laquito and Laco Sur (Fig. 1) (Henríquez et al., 2004). The similar features include sharp ore-rock contacts and an equigranular texture of the magnetite. A magmatic origin is supported by the existence of microlitic plagioclase rims in well-preserved andesite host rocks.

The second stage is interpreted as an episode of contact metasomatism caused by the intrusion of an iron-oxide magma at a subvolcanic level. The stage is characterized by development of magnetite veinlets with halos of hematite due to oxidation, and intense scapolitization. Pyroxene and subordinate garnet, titanite, apatite and mica were also formed. At depth, the alteration resulted in almost complete replacement of the andesite (-dacite) clasts with formation of scapolite-magnetite rock (Fig. 3b). The effects of the metasomatism decrease towards the surface, where it is visible as reaction rims.

The third stage is of hydrothermal character and its effects are present mainly in the uppermost parts of the drill cores. They include pyrite-bearing magnetite veins and veinlets, pyrite dissemination in the breccia matrix and andesite fragments, and microscopic veinlets of pyrite cutting magnetite. The scarce chalcopyrite disseminated in the breccia matrix also belongs to this stage.

The fourth stage is interpreted as a hydrothermalgeothermal process that represents the last alteration
TABLE 2. CHARACTERISTIC MINERALS RELATED TO THE DIFFERENT METASOMATIC-HYDROTHERMAL ALTERATION STAGES AT PASOS BLANCOS, ELVC.

\begin{tabular}{|c|c|c|c|c|}
\hline Mineral & Stage 1 & Stage 2 & Stage 3 & Stage 4 \\
\hline Magnetite & & & & \\
\hline Scapolite & & & & \\
\hline Pyroxene & & & & \\
\hline Titanite & & & & \\
\hline Garnet & & & & \\
\hline Apatite & & & & \\
\hline Mica & & & & \\
\hline Pyrite & & & & \\
\hline Chalcopyrite & & & & \\
\hline Gypsum & & & & \\
\hline Natrolite & & & & \\
\hline Bassanite & & & & \\
\hline Alunite & & & & \\
\hline Tridymite & & & & \\
\hline
\end{tabular}

event. It is characterized by abundant gypsum filling open spaces mainly within the breccia matrix. Other minerals associated with this stage are natrolite, bassanite, alunite and tridymite. The presence of steam vents and hot springs where magnetite had been oxidized to hematite, together with deposition of sulphur, gypsum, white clay minerals and possibly alunite, may reveal that this stage is still active.

\section{Discussion}

Our genetic model for the alteration in the Pasos Blancos drill cores and its relationship to the iron-oxide deposits at El Laco is as follows. Shallow-level emplacement of volatile-rich ironoxide magma, with discharge of volatiles which resulted in extensive fracturing of overlying volcanic rocks in the ELVC. Intrusion of volatile-rich magma and consequent fracturing greatly increased 
m a.s.l.
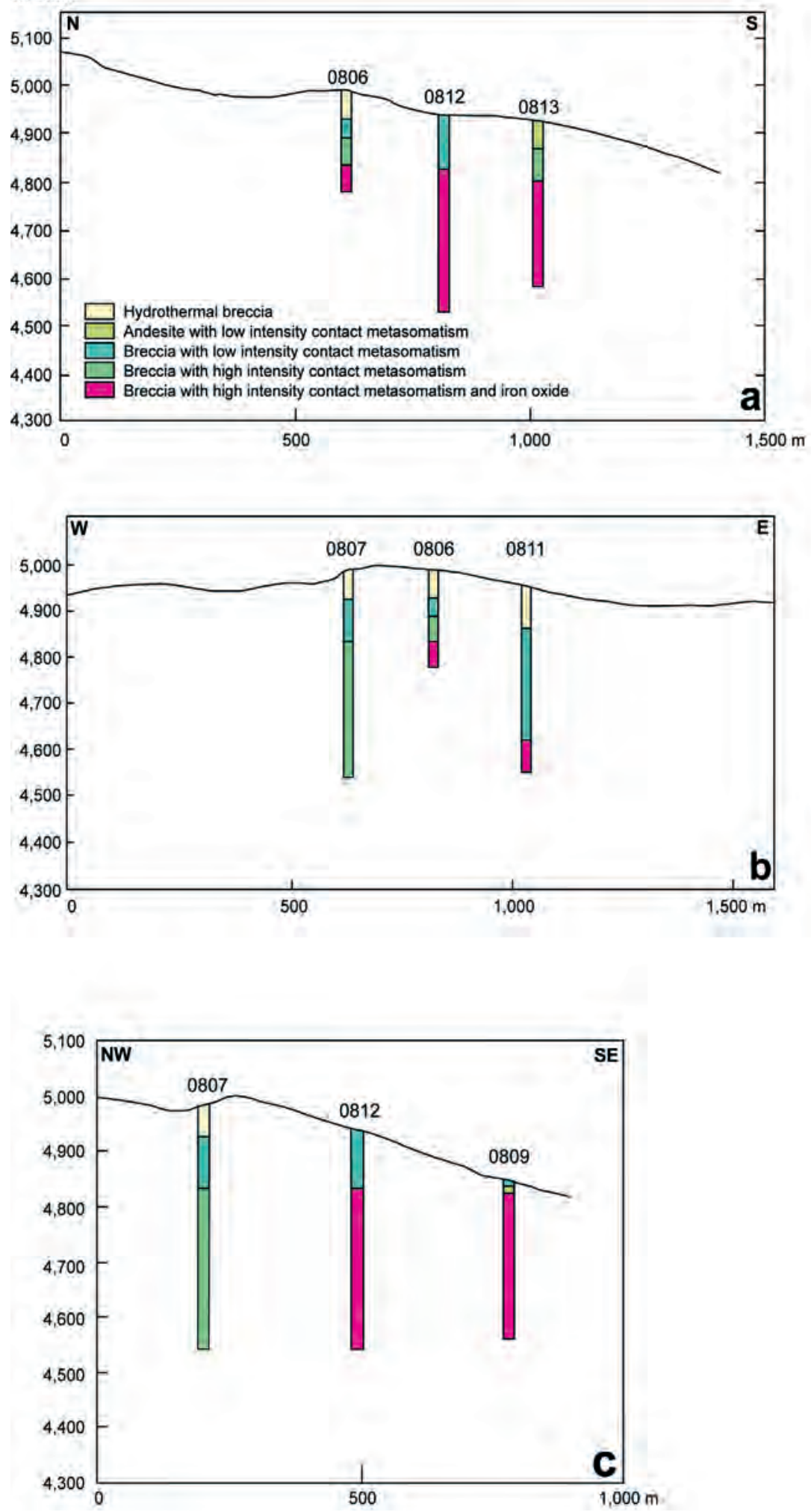

FIG. 5. Schematic illustration of alteration intensity in the drill cores within three profiles at Pasos Blancos (for location see Fig. 1). 
the permeability of the host rock (Meinert et al., 2005). The brecciated rocks were altered (mainly extensive scapolitization and formation of pyroxene) by hot magmatic fluids emitted from the cooling intrusion, and magnetite was deposited. The role of hot metasomatic fluids is supported by the existence of very F-rich mica. With time and decreasing temperature, the metasomatic fluids evolved to fluids of more hydrothermal character, and a final recent geothermal event took place that deposited superficial gypsum over a large part of the ELVC. This interpretation is in agreement with magnetic modelling by Alva et al. (2003) that inferred the presence of a large magnetite-bearing body at depth in the Pasos Blancos area.

The textural and mineralogical features described here for the altered volcanic rocks at El Laco differ from corresponding features and protoliths reported for iron skarns in the literature (Meinert et al., 2005) and they are similar to those present at Kirunavaara (Romer et al., 1994) and Olympic Dam (Roberts and Hudson, 1983). The estimated thickness of the volcanic sequence affected by the metasomatic process at Pasos Blancos is at least $450 \mathrm{~m}$ (Fig. 5), which corresponds to a great volume of rock. This requires a sizeable source of heat and volatiles. We suggest that this source was the emplacement of iron-oxide magma that is postulated to form a large intrusive body at depth below Pasos Blancos.

\section{Conclusions}

A contact-metasomatic process affecting a $>450 \mathrm{~m}$ thick pile of volcanic rocks in the Pasos Blancos area at El Laco is well defined in drill cores by the occurrence and distribution of scapolite and pyroxene. As far as we know, this kind of process has not yet been described associated with young volcanism elsewhere.

The multi-stage alteration process reported here is proposed to be a characteristic feature associated with shallow-level emplacement of intrusive ironoxide bodies.

Scapolite is a typical characteristic mineral associated with IOCG ore deposits (Williams et al., 2005). The close relationship between magnetite-apatite ore and scapolitization at El Laco, together with the presence of chalcopyrite in the hydrothermal phase, indicates a genetic link between these ore types, both possibly derived from iron-oxide magmas (Naslund et al., 2002).

\section{Acknowledgments}

The authorization to access the CMP's drill cores were given by colleagues L. Vergara and M. Rojo, managers of the company. Their support is highly appreciated by the authors. Valuable comments given by the editor, N. Badham, S. Ghandi, T. Spooner and an anonymous reviewer have allowed original manuscript improvement. This is a contribution to the Fondecyt Project $N^{\circ} 1070428$.

\section{References}

Alva-Valdivia, L.M.; Rivas, M.L.; Goguitchaichvili, A.; Urrutia-Fucugauchi, J.; González, J.A.; Morales, J.; Gómez, S.; Henríquez, F.; Nyström, J.O.; Naslund, H.R. 2003. Rock-magnetic and oxide microscopic studies of the El Laco iron-ore deposits, Chilean Andes, and implications for magnetic anomaly modelling. International Geology Review 45 (6): 533-547.

Gardeweg, M.; Ramírez, C.F. 1985. Hoja Río Zapaleri, II Región de Antofagasta, Santiago, Chile. Servicio Nacional de Geología y Minería, Carta Geológica de Chile 66: $89 \mathrm{p}$

Hammerschmidt, K.; Grosjean, M.; Pedroni, A.; Friedrichsen, H. 1999. Cosmogenic He and Ne dating of glacial striae, polished surfaces and moraine boulders in the Chilean high cordillera $\left(22^{\circ}-28^{\circ} \mathrm{S}\right)$. Journal of Conference Abstracts 4 (1): EUG 10, Syposium B01.

Henríquez, F.; Naslund, H.R.; Nyström, J.O.; Vivallo, W.; Aguirre, R.; Dobbs, F.M.; Lledó, H. 2003. New field evidence bearing on the origin of the El Laco magnetite deposit, Northern Chile-A discussion. Economic Geology 98: 1497-1502.

Henríquez, F.; Naslund, H.R.; Nyström, J.O.; Naranjo, J.A. 2004. Igneous textures in magnetite eruptive products at El Laco, Chile. In International Association of Volcanology and Chemistry of the Earth's Interior (IAVCEI), General Assembly (abstract and poster). Pucón-Chile.

Larson, A.C. 1994. Evidence of pneumatolytic processes in the genesis of magnetite deposits at El Laco, Chile. M.Sc. Thesis (Unpublished), Dartmouth College, New Hampshire: 51 p.

Maksaev, V.; Gardeweg, M.; Ramírez, C.F.; Zentilli, M. 1988. Aplicación del método trazas de fisión (fission track) a la datación de cuerpos de magnetita de El Laco e Incahuasi en el altiplano de la Región de Antofagasta. In Congreso Geológico Chileno, No. 5, Actas 1: B1-B23. Santiago.

Meinert, L.D.; Dipple, G.M.; Nicolescu, S. 2005. World skarn deposits. In Economic Geology 100th Anniver- 
sary Volume (Hedenquist, J.W.; Thompson, J.F.H.; Goldfarb, R.J.; Richards, J.P.; editors). Society of Economic Geologists: 299-336. Littleton.

Naranjo, J.A.; Henríquez, F.; Naslund, H.R.; Nyström, J.O. 2004. Rare iron oxide eruptive products at El Laco volcanic complex, Central Andes, Chile. In International Association of Volcanology and Chemistry of the Earth's Interior (IAVCEI), General Assembly (abstract). Pucón-Chile.

Naranjo, J.A.; Henríquez, F.; Andrade, B. 2008. Ages for the iron oxide volcanism at El Laco Volcanic Complex, central Andes. In International Association of Volcanology and Chemistry of the Earth's Interior (IAVCEI), General Assembly (abstract). Iceland.

Naslund, H.R.; Henríquez, F.; Nyström, J.O.; Vivallo, W.; Dobbs, M. 2002. Magmatic iron ores and associated mineralization: Examples from the Chilean High Andes and Coastal Cordillera. In Hydrothermal Iron Oxide Copper-Gold \& Related Deposits: A Global Perspective (Porter, T.M.; editor). Porter GeoConsultancy (PGC) Publishing 2: 207-226. Adelaide.

Nyström, J.O.; Billström, K.; Henríquez, F.; Fallick, A.E.; Naslund, R.H. 2008 Oxygen isotope composition of magnetite in iron ores of the Kiruna type from Chile and Sweden. GFF 130: 177-188.

Oreskes, N.; Rhodes, A.L.; Rainville, K.; Sheets, S.; Espinoza, S.; Zentilli M. 1994. Origins of magnetite deposits at El Laco Chile: new evidence from field studies, fluid inclusions, stable isotopes, and fission track analyses. Annual Meeting of the Geological Society of America, Abstracts with Programs 26: A-379.

Park, C.F. 1961. A magnetite 'flow' in northern Chile. Economic Geology 80: 646-665.

Rhodes, A.L.; Oreskes, N. 1994. The magnetite 'lava flows (?)', El Laco, Chile: new evidence for formation by vapor transport. In Congreso Geológico Chileno, No. 7, Actas 2: 1501-1505. Concepción.
Rhodes, A.L.; Oreskes, N. 1995. Magnetite deposition at El Laco, Chile: implications for Fe-oxide formation in magmatic-hydrothermal systems. In Giant ore deposits-II: Controls on the scale of orogenic magmatic-hydrothermal mineralization (Clark, A.H.; editor). Proceedings of the Second Giant Ore Deposits Workshop, Queen's University: 582-622. Kingston, Ontario, Canada.

Rhodes, A.L.; Oreskes, N. 1999. Oxygen Isotope composition of magnetite deposits at El Laco, Chile: Evidence of formation from isotopically heavy fluids. Society of Economic Geology, Special Publication 7: 333-351.

Rhodes, A.L.; Oreskes, N.; Sheets, S. 1999. Geology and rare earth element geochemistry of magnetite deposits at El Laco, Chile. Society of Economic Geology, Special Publication 7: 299-332.

Roberts, D.E.; Hudson, G.R.T. 1983. The Olympic Dam copper-uranium-gold deposit, Roxby Downs, South Australia. Economic Geology 78: 799-822.

Romer, R.L.; Martinsson, O.; Perdahl, J.-A. 1994. Geochronology of the Kiruna iron ores and hydrothermal alterations. Economic Geology 89: 1249-1261.

Sillitoe, R.H.; Burrows, D.R. 2002. New field evidence bearing on the origin of the El Laco magnetite deposit, Northern Chile. Economic Geology 97: 1101-1109.

Sillitoe, R.H. 2003. New field evidence bearing on the origin of the El Laco magnetite deposit, Northern Chile-A reply. Economic Geology 98: 1501-1502.

Williams, P.J.; Barton, M.D.; Johnson, D.A.; Fontboté, L.; de Haller, A.; Mark, G.; Oliver, N.H.S.; Marschik, R. 2005. Iron oxide copper-gold deposits: Geology, space-time distribution, and possible modes of origin. In Economic Geology $100^{\text {th }}$ Anniversary Volume (Hedenquist, J.W.; Thompson, J.F.H.; Goldfarb, R.J.; Richards, J.P.; editors). Society of Economic Geologists: 371-405. Littleton. 